\title{
Front Matter: Volume 11029
}

, "Front Matter: Volume 11029," Proc. SPIE 11029, Micro-structured and Specialty Optical Fibres VI, 1102901 (17 July 2019); doi: 10.1117/12.2535408

SPIE. Event: SPIE Optics + Optoelectronics, 2019, Prague, Czech Republic 


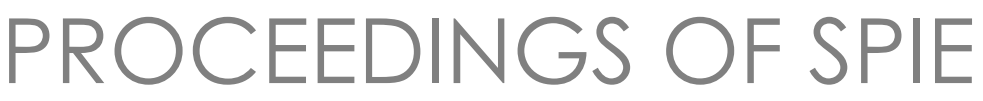

\section{Micro-structured and Specialty Optical Fibres VI}

Kyriacos Kalli

Alexis Mendez

Pavel Peterka

Editors

3-4 April 2019

Prague, Czech Republic

Sponsored by

SPIE

Cooperating Organisations

ELI Beamlines (Czech Republic)

Laserlab Europe

European Optical Society

HiLASE (Czech Republic)

Published by

SPIE 
The papers in this volume were part of the technical conference cited on the cover and title page. Papers were selected and subject to review by the editors and conference program committee. Some conference presentations may not be available for publication. Additional papers and presentation recordings may be available online in the SPIE Digital Library at SPIEDigitalLibrary.org.

The papers reflect the work and thoughts of the authors and are published herein as submitted. The publisher is not responsible for the validity of the information or for any outcomes resulting from reliance thereon.

Please use the following format to cite material from these proceedings:

Author(s), "Title of Paper," in Micro-structured and Specialty Optical Fibres VI, edited by Kyriacos Kalli, Alexis Mendez, Pavel Peterka, Proceedings of SPIE Vol. 11029 (SPIE, Bellingham, WA, 2019) Seven-digit Article CID Number.

ISSN: 0277-786X

ISSN: 1996-756X (electronic)

ISBN: 9781510627246

ISBN: 9781510627253 (electronic)

Published by

SPIE

P.O. Box 10, Bellingham, Washington 98227-0010 USA

Telephone +1360 676 3290 (Pacific Time) · Fax +1 3606471445

SPIE.org

Copyright @ 2019, Society of Photo-Optical Instrumentation Engineers.

Copying of material in this book for internal or personal use, or for the internal or personal use of specific clients, beyond the fair use provisions granted by the U.S. Copyright Law is authorized by SPIE subject to payment of copying fees. The Transactional Reporting Service base fee for this volume is $\$ 18.00$ per article (or portion thereof), which should be paid directly to the Copyright Clearance Center (CCC), 222 Rosewood Drive, Danvers, MA 01923. Payment may also be made electronically through CCC Online at copyright.com. Other copying for republication, resale, advertising or promotion, or any form of systematic or multiple reproduction of any material in this book is prohibited except with permission in writing from the publisher. The CCC fee code is $0277-$ $786 \times / 19 / \$ 18.00$.

Printed in the United States of America by Curran Associates, Inc., under license from SPIE.

Publication of record for individual papers is online in the SPIE Digital Library.

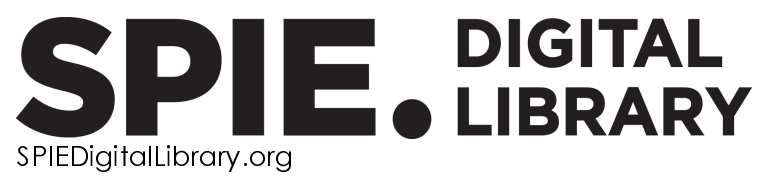

Paper Numbering: Proceedings of SPIE follow an e-First publication model. A unique citation identifier (CID) number is assigned to each article at the time of publication. Utilization of CIDs allows articles to be fully citable as soon as they are published online, and connects the same identifier to all online and print versions of the publication. SPIE uses a seven-digit CID article numbering system structured as follows:

- The first five digits correspond to the SPIE volume number.

- The last two digits indicate publication order within the volume using a Base 36 numbering system employing both numerals and letters. These two-number sets start with $00,01,02,03,04$, 05, 06, 07, 08, 09, OA, OB ... 0Z, followed by 10-1Z, 20-2Z, etc. The CID Number appears on each page of the manuscript. 


\title{
Contents
}

\author{
$\checkmark \quad$ Authors \\ vii Conference Committee \\ ix Introduction
}

SESSION 1 PHOTONIC CRYSTAL FIBERS AND HOLLOW CORE FIBERS

$1102904 \quad \mathrm{OH}$ diffusion effects at preparation of antiresonant hollow core fibers [1 1029-5]

SESSION 2 MID-IR AND INFRARED FIBERS AND COHERENT SOURCES

1102908 Spectroscopic characterization of holmium-doped optical fibers for fiber lasers [1 1029-8]

1102909 Experimental investigation and characterization of fabrication shaped clad optical fiber by thermally polishing optical fiber preforms with $\mathrm{CO}_{2}$ laser [1 1 029-9]

SESSION 3 FIBER BRAGG GRATINGS AND POLYMER OPTICAL FIBERS

11029 OC Ultrafast fiber Bragg grating inscription in DPDS-core doped POF using 325 nm laser [1 1029-12]

11029 OE Direct core-selective inscription of Bragg grating structures in seven-core optical fibers by femtosecond laser pulses [1 1029-14]

11029 OF Femtosecond laser plane-by-plane Bragg gratings for monolithic Thulium-doped fibre laser operating at $1970 \mathrm{~nm}$ [11029-15]

\section{SESSION $4 \quad$ OPTICAL FIBERS FOR BIOMEDICAL APPLICATIONS}

11029 OK Towards poly(D,L-lactic acid)-based biodegradable and biocompatible polymer optical fiber (Best Student Paper Award) [1 1029-20]

\section{SESSION $5 \quad$ SENSORS AND DEVICES BASED ON SPECIALTY FIBERS}

11029 OL RGB wavelength demultiplexer based on PCF/POF structure [1 1029-30] 
11029 OM Pulse compression in defective core photonic crystal fiber [1 1029-23]

11029 ON Depolarization of light in optical fibers [1 1029-24]

\section{SESSION 6 MODELLING AND ANALYSIS OF SPECIALTY FIBERS AND COMPONENTS}

$110290 Q \quad$ Complete dispersion characterization of microstructured optical fibers using windowed Fouriertransform spectral interferometry [1 1029-27]

11029 OR Strongly coupled multi-core fiber-based interferometer for high temperature sensing [1 1029-28]

11029 OS Combined implementation of controllable beam splitting and wavelength division multiplexing using tunable interference wedged structures [1 1029-29]

\section{POSTER SESSION}

11029 OT Arrays of microstructured MIR fibers based on silver halides for medical applications [1 1029-31]

11029 OU Microscopic mechanisms of radiation-induced light attenuation in pure silica-core fibers: influence of heat treatment in the process of metal and polyimide coating application [1 1029-32]

11029 OV Gamma-radiation-induced attenuation of light in polarization-maintaining pure-silica-core PANDA fibers [1 1029-33]

11029 oY Coupling of self-written waveguides (SWW) in photopolymer and reverse manipulation [1 1029-36]

$1102910 \quad$ Capillary optical fiber with a Bragg mirror of arsenic sulfide and polymers applied onto the inner capillary wall [1 1029-39]

$1102911 \quad$ High-power laser tests of phosphate glass-based bioresorbable optical fibers transmission [1 1029-40] 


\section{Authors}

Numbers in the index correspond to the last two digits of the seven-digit citation identifier (CID) article numbering system used in Proceedings of SPIE. The first five digits reflect the volume number. Base 36 numbering is employed for the last two digits and indicates the order of articles within the volume. Numbers start with 00, 01, 02, 03, 04, 05, 06, 07, 08, 09, OA, OB...0Z, followed by 10-12, 20-2Z, etc.

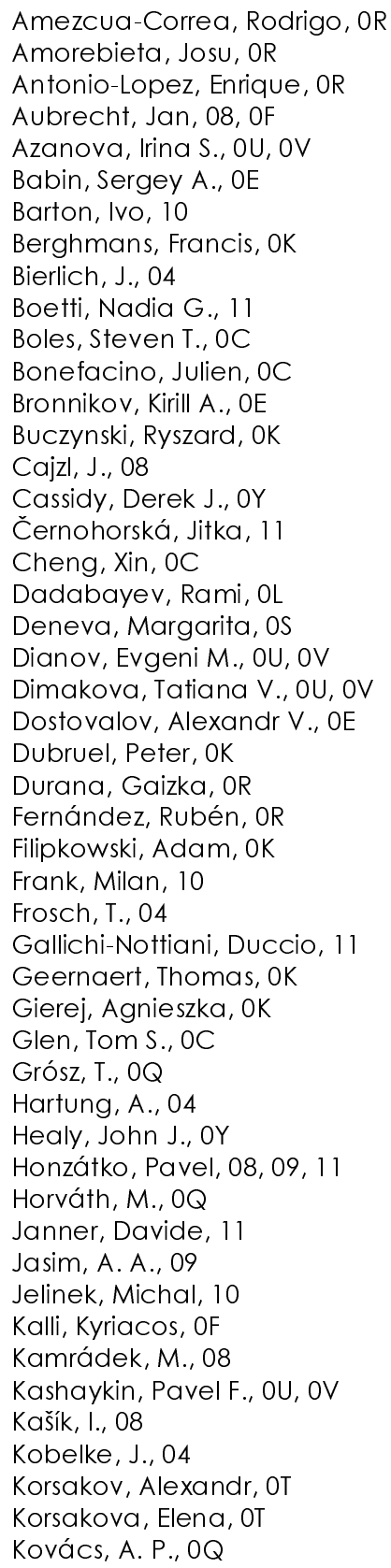

Kubeček, Václav, 08, 10

Lorenz, A., 04

Malka, Dror, OL

Maltsev, Igor A., OU, OV

Matějec, Vlastimil, 10

Milanese, Daniel, 11

Mrázek, J., 08

Muftahitdinova, Natalia, OT

Mulallah, Ra'ed, OY

Nagyillés, B. G., OQ

Nenchev, Marin, OS

Nithyanandan, K., OM

Ortega-Gomez, Angel, OR

Pedlikova, Jitka, 10

Peterka, Pavel, 08, 09, OF, 11

Petrov, N. I., ON

Písařík, Michael, 11

Podrazký, Ondřej, 08, 09, 11

Pospelova, Elena A., OU, OV

Pugliese, Diego, 11

Sáez de Ocáriz, Idurre, OR

Schmidt, M. A., 04

Schülzgen, Axel, OR

Schuster, K., 04

Schwuchow, A., 04

Sharafali, A., OM

Sharonova, Yulia O., OU, OV

Sheridan, John T., OY

Siwicki, Bartlomiej, OK

Stoykova, Elena, OS

Tam, Hwa-Yaw, OC

Theodosiou, Antreas, OF

Thienpont, Hugo, OK

Todorov, F., 09

Tomashuk, Alexander L., OU, OV

Turčičová, Hana, 11

Vagenende, Maxime, OK

Van Vlierberghe, Sandra, OK

Varák, Petr, 11

Velasco, Javier, OR

Villatoro, Joel, OR

Vokhmyanina, Olga L., OU, OV

Vuković, K., OQ

Wan, Min, OY

Wolf, Alexey A., OE

Wondraczek, K., 04

Zhukova, Liya, OT

Zubia, Joseba, OR 
Proc. of SPIE Vol. 11029 1102901-6

\section{Downloaded From: https://www.spiedigitallibrary.org/conference-proceedings-of-spie on 26 Apr 2023
Terms of Use: https://www.spiedigitallibrary.org/terms-of-use}




\title{
Conference Committee
}

\author{
Symposium Chairs
}

Bedrich Rus, ELI Beamlines, Institute of Physics of the CAS, v.v.i. (Czech Republic)

Chris Edwards, STFC Rutherford Appleton Laboratory

(United Kingdom)

Saša Bajt, Deutsches Elektronen-Synchrotron (Germany)

Ivo Rendina, Istituto per la Microelettronica e Microsistemi (Italy)

Mike Dunne, SLAC National Accelerator Laboratory (United States)

Honorary Symposium Chair

Erich Spitz, French Academy of Sciences, National Academy of Technologies (France), Advisor to Thales (France)

\section{Conference Chairs}

Kyriacos Kalli, Cyprus University of Technology (Cyprus)

Alexis Mendez, MCH Engineering LLC (United States)

Pavel Peterka, Institute of Photonics and Electronics of the CAS, v.v.i. (Czech Republic)

\section{Conference Programme Committee}

Jean-Luc Adam, Université de Rennes 1 (France) John Ballato, Clemson University (United States)

Ole Bang, DTU Fotonik (Denmark)

Hartmut Bartelt, Institut für Photonische Technologien e.V. (Germany)

Neil G. R. Broderick, The University of Auckland (New Zealand)

Benjamin J. Eggleton, The University of Sydney (Australia)

Christopher Emslie, Fibercore Ltd. (United Kingdom)

Sebastien Fevrier, XLIM Institut de Recherche (France)

Karl-Friedrich Klein, Technische Hochschule Mittelhessen (Germany)

Jonathan C. Knight, University of Bath (United Kingdom)

Michael Komodromos, Frederick University (Cyprus)

Hanne Ludvigsen, Aalto University School of Science and Technology (Finland)

Walter Margulis, Acreo Swedish ICT AB (Sweden)

Saeed Rehman, Fibercore Ltd. (United Kingdom)

Valerio Romano, Berner Fachhochschule Technik und Informatik

(Switzerland)

Kay Schuster, Institut für Photonische Technologien e.V. (Germany) 
Waclaw Urbanczyk, Wroclaw University of Technology (Poland)

David J. Webb, Aston University (United Kingdom)

Alexei M. Zheltikov, Lomonosov Moscow State University

(Russian Federation)

\section{Session Chairs}

1 Photonic Crystal Fibers and Hollow Core Fibers

Kyriacos Kalli, Cyprus University of Technology (Cyprus)

2 Mid-IR and Infrared Fibers and Coherent Sources

Markus A. Schmidt, Leibniz-Institut für Photonische Technologien e.V. (Germany)

3 Fiber Bragg Gratings and Polymer Optical Fibers

Laetitia C. Petit, Tampere University (Finland)

4 Optical Fibers for Biomedical Applications

Ivan Kašík, Institute of Photonics and Electronics of the CAS, v.v.i. (Czech Republic)

5 Sensors and Devices Based on Specialty Fibers

Pavel Honzátko, Institute of Photonics and Electronics of the CAS, v.v.i. (Czech Republic)

6 Modelling and Analysis of Specialty Fibers and Components

Pavel Peterka, Institute of Photonics and Electronics of the CAS, v.v.i. (Czech Republic) 


\section{Introduction}

This proceedings volume is from Micro-structured and Specialty Optical Fibres VI, held on Wednesday and Thursday 3-4 April 2019, at the symposium SPIE Optics+Optoelectronics in Prague, Czech Republic. The conference was collocated with the special events of the Optical Fiber Technology Workshop and lab tour in optical fibre technology laboratory at the Institute of Photonics and Electronics of the Czech Academy of Sciences that were organized on Tuesday, 2 April 2019.
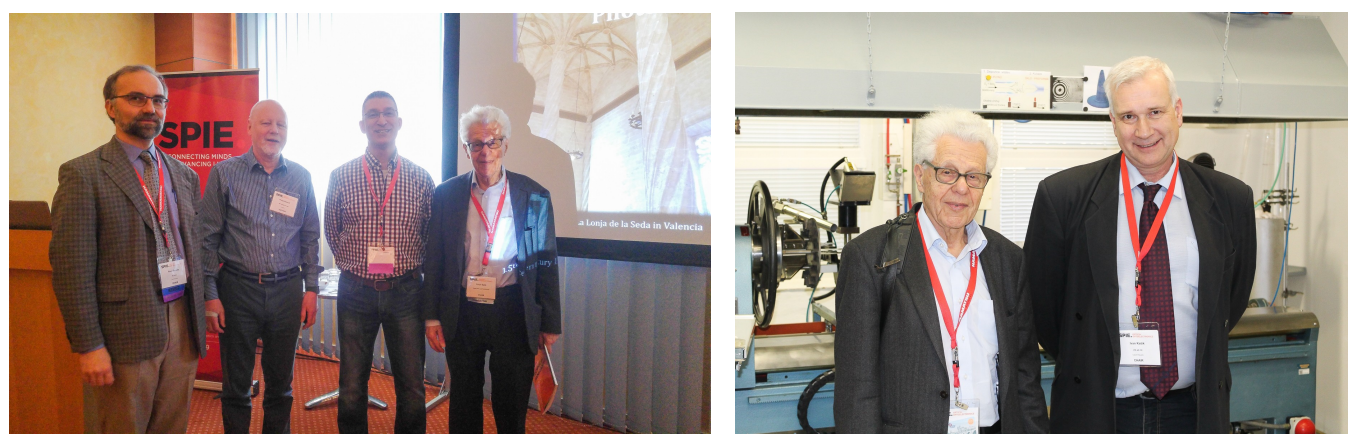

Left photo: The conference started with keynote lecture of Prof. Philip St. John Russell, the inventor of photonic crystal fibres. From left: Pavel Peterka, Philip St. John Russell, Kyriacos Kalli, and Erich Spitz, honorary chairman of the symposium SPIE Optics+Optoelectronics.

Right photo: Erich Spitz, the co-author of the first single-mode optical fibre for transmission of information, together with Ivan Kašik, chairman of the Optical Fibre Technology Workshop, during the lab tour.

This conference aimed to provide a forum for scientists and engineers-involved with the modelling, design, fabrication, device integration, and application of PCFs and specialty optical fibres-to present and share their latest research and findings. Moreover, this conference expanded on the existing innovations that relate to microstructure and specialty optical fibres, detailing progress in the areas of fibre manufacture, devices, and applications that target the fields of optical communications, fibre lasers, sensing and spectroscopy; and incorporating modelling of novel fibre geometries. Papers focused mainly on the following topics:

Materials, Processes and Fabrication Advances: Advances in speciality and microstructure fibre manufacture based on, silica, chalcogenide and multicomponent glasses, rare-earth doped fibres, single crystal material fibre and polymer optical fibres, as well as new and advanced coating materials. 
Theory and Modeling: Modelling and simulation of linear and nonlinear characteristics of novel optical fibres, including modal analysis, birefringence, polarisation and dispersion properties, confinement and bending losses, evanescent coupling in multi- core fibre and fibre tapers

Test and Characterisation Methods: Characterisation of optical fibres, e.g. measurements of fibre geometry, birefringence, dispersion, non-linearity and distributed measurements

Optical Components, Sensors and Devices: Speciality and microstructure fibrebased devices and their applications cover a broad spectrum of research areas that can include: Supercontinuum generation, wavelength conversion, fibre lasers and amplification, ultra-high power and ultra-short pulse delivery, optical clocks, pulse shaping, dispersion compensation, micro fluidic devices, liquid crystal fibres, and optical transport of microparticles, optical fibre sensors, e. $\mathrm{g}$. chemical and biosensors, vectorial (multi-core structures) and birefringent sensors (temperature and pressure); Bragg and long period grating sensors in specialised fibres; near-field microscopy, spectroscopy of gases and liquids.

The sixth bi-annual conference presented 36 papers, 27 of them were presented in 6 oral sessions and 9 of them in a poster session. Here are the keynote and invited talks of the program:

\section{Keynote:}

Philip St. John Russell, Max-Planck-Institut für die Physik des Lichts (Germany), Paul Roth, Y. Chen, Gordon Wong, "The curious properties of twisted photonic crystal fibres" [1 1029-1]

Invited:

Markus A. Schmidt, Leibniz-Institut für Photonische Technologien e.V. (Germany), "Optofluidic microstructured fibers: detecting freely diffusing nanoobjects via dynamic light scattering" [1 1029-21]

Ryszard Buczynski, Institute of Electronic Materials Technology (Poland), University of Warsaw (Poland), Alicja Anuszkiewicz, Marcin Franczyk, Adam Filipkowski, et al. "Nanostructured core optical fibres" [1 1029-6]

Shyam S. Bayya, U.S. Naval Research Laboratory (United States), Woohong Kim, Brandon Shaw, Jason Myers, et al., "All-crystal fiber lasers" [1 1029-7]

Andreas loannou, Cyprus Univ. Of Technology (Cyprus) and Univ. de Mons (Belgium), Antreas Theodosiou, Christophe Caucheteur, Kyriacos Kalli, "The modal behaviour of plane-by-plane femtosecond laser fabricated tilted fibre Bragg gratings" [1 1029-6]

Tomáš Čižmár, Leibniz-Instituł für Photonische Technologien e.V. (Germany), "Harnessing multimode propagation for deep tissue imaging" [1 1029-17]

Laeticia C. Petit, University of Tampere (Finland), "Fabrication and 
characterization of phosphate biophotonic fibers" [1 1029-18]

Laurent Labonté, Institut de Physique de Nice (France), Florent Mazeas, Mattis Reimer, Rachel Cannon, et al., "Quantum metrology for fiber laser applications" [1 1029-26]

Optical Fiber Technology Workshop, the collocated special event, contained a series of tutorial and invited lectures focused on advanced fabrication methods of optical fibers and optical fiber components. Following the Workshop, registered participants were invited to a tour of the laboratory for fabrication of specialty optical fibres for fibre lasers and optical fibre sensors, part of the Institute of Photonics and Electronics (ÚFE) of the Czech Academy of Sciences. The Workshop and the lab tour were organized alongside the commemoration of 40 years of research of optical fiber technology in the Czech Republic. Special acknowledgement goes to the Strategy AV21 of the Czech Academy of Sciences and its program 'Light at the service of society', who supported these special events.

List of lectures from the Workshop:

Erich Spitz, French Academy of Sciences, National Academy of Technologies, Advisor to Thales (France), "Some original ideas and coherent light experiments during the sixties at the Central Research Laboratory of CSF Company (later Thomson-CSF, today Thales)" (Invited Presentation)

Pavel Honzátko, Institute of Photonics and Electronics of the Czech Academy of Sciences (Czech Republic), "Future trends in optical fibers" (Invited Presentation)

Kyriacos Kalli, Cyprus University of Technology (Cyprus), "Femtosecond-Iaser processing of optical fibers: component development with applications to lasers and sensors" (Tutorial)

Laeticia C. Petit, University of Tampere (Finland), "Optical fiber preform preparation" (Tutorial)

Overall, this sixth bi-annual conference has continued to serve as a catalyst for the growth of the expanding area of specialty optical fibers and their applications in fibre lasers, optical fibre sensors, telecommunications, biomedicine and other important human activities. We hope you will enjoy the papers submitted for this volume. 
Proc. of SPIE Vol. 11029 1102901-12

Downloaded From: https://www.spiedigitallibrary.org/conference-proceedings-of-spie on 26 Apr 2023 Terms of Use: https://www.spiedigitallibrary.org/terms-of-use 